\title{
Effect of Machining Process in Superfinish Turning on the Corrosion Behavior of UNS S31600 Stainless Steel in $6 \%$ NaCl Solution
}

\author{
Y. Ech-Charqy, ${ }^{a, b,{ }^{*}}$ H.Gziri ${ }^{b}$ and M.Essahli ${ }^{a}$ \\ ${ }^{a}$ University Hassan 1, Laboratory of Applied Chemistry and Environment, \\ BP 577 Settat, Morocco \\ ${ }^{b}$ University Hassan 1, Laboratory of Mechanic, Industrial Management and Innovation, \\ BP 577 Settat, Morocco
}

Received 18 April 2016; accepted 30 April 2016

\begin{abstract}
The influence of surface topography and cutting parameters on the corrosion resistance of stainless steel UNS S31600 in a $6 \% \mathrm{NaCl}$ solution is addressed in the present study. Surface topography has been modified by changing the conditions parameters of superfinish turning, including feed, cutting speed and depth of cut, and their correlations with corrosion resistance have been examined. The results showed that the depth of cut is correlated with the corrosion potential. Moreover, the increase of cutting speed degrades the corrosion resistance and increases the corrosion potential in the anodic phase. In its turn, the polarization resistance increases in a manner correlated with increasing the surface quality.
\end{abstract}

Keywords: Pitting corrosion; polarization resistance; average roughness; superfinish turning; potentio-dynamic test.

\section{Introduction}

Superfinish turning is a machining process that has become increasingly important in industry. It consists to avoid the rectification phase in order to have a good quality of machined surface [1]. This process is developed in mechanical industry, in particular, when the functional performance and the safe life of workpiece are essential requirements [2]. Many experimental and analytical studies were performed to quantify the influence of these cutting conditions on the surface topography [3-5], residual stresses [6-8] and microstructure $[9,10]$ of pure metals and metal alloys.

In literature, many investigations claim that the cutting conditions of the turning machining, induce a field of the residual stresses in the inside layer near

\footnotetext{
* Corresponding author. E-mail address: y.echcharqy@uhp.ac.ma
} 
machined surface. They significantly modify the microstructure, the texture of the workpiece, and its mechanical properties [11,12]. So, the electrochemical behavior and the corrosion resistance can be also affected.

Some research has proven that the corrosion behavior has been effected by machining [13,14]. Szklarska-Smialowska has confirmed that the more the surface is homogeneous, chemically and physically, the more the pitting potential is increased, and the number of pits is weak, consequently the best corrosion resistance of the metal [15]. Zuo et al. [16] have affirmed that the number of metastable pits, of stainless steel, decreases with increasing the number of grains of the paper at a given potential. Similar results were obtained by Sasaki and Burstein [17]. They reported that the pitting potential is lower for rougher surfaces than for smoother. Zatkalíková and Liptáková [18] affirmed this result; they found that the potential and the corrosion rate decreases with the decrease in the value of the average roughness of UNS S30400. M. Prakash et al. [19] have found that the corrosion rate decreases with the increase in the cutting speed in turning operation, and it increases with the decrease in the cutting angle. However, Sang Mok Lee et al. [20] have proved that the polarization resistance has not a significant correlation with the average roughness of mashed stainless steel. Yet, they founded that it has a significant variation with the height of the pits.

Gravier et al. [21] have observed that the electrochemical behavior of workpiece is influenced by the mechanical and microstructural properties in $\mathrm{NaClO}_{4}$ electrolyte solution at $25^{\circ} \mathrm{C}$; they adapted in their research the electrochemical microcell technique. Similarly, Bissey-Breton et al. [22] were remarked that the surface roughness and the residual stress are strongly correlated with the corrosion potential. Yin et al. [23] have also shown that the granular microstructure affects the distribution of the residual stress, which affects the wear corrosion of copper surfaces when exposed to $\mathrm{NaCl}$ solution. So, Robin et al. [24] have found that the corrosion resistance of copper decreases with the intensity of the stress induced by the stamping process.

In this work, an empirical study will be established to find a correlation of the cutting conditions and the arithmetic average roughness, with the corrosion behavior of the workpiece in superfinish turning, especially with the corrosion potential, the current density and the polarization resistance.

\section{Presentation of experimental tests Material studied}

This is a stainless steel alloy UNS S31600 type 16Cr-10NI, with austenitic structure. It comes in rolled form. The chemical composition of the stainless steel is given in Table 1. UNS S31600 stainless steel was subjected to a tensile test, to determine its mechanical behavior. Table 2 shows that the selected steel has high tensile stress $730 \mathrm{MPa}$, and its elastic limit reached $551 \mathrm{MPa}$.

Table 1. Chemical composition of UNS S31600.

\begin{tabular}{ccccccccccc}
\hline $\mathbf{C}$ & $\mathbf{S i}$ & $\mathbf{M n}$ & $\mathbf{P}$ & $\mathbf{S}$ & $\mathbf{N}$ & $\mathbf{C r}$ & $\mathbf{M o}$ & $\mathbf{N i}$ & $\mathbf{C u}$ & $\mathbf{C o}$ \\
\hline $\mathbf{0 . 0 2 2}$ & 0.37 & 1.79 & 0.031 & 0.026 & 0.075 & 16.59 & 2.08 & 10.13 & 0.36 & 0.16 \\
\hline
\end{tabular}


Table 2. Tensile test of UNS S31600.

\begin{tabular}{cccc}
\hline Rm (Mpa) & Pr02 (Mpa) & A5 \% & Z \% \\
\hline $\mathbf{7 3 0}$ & 551 & 41.3 & 71.8 \\
\hline
\end{tabular}

\section{Superfinish turning}

The experiment was conducted on a CNC lathe. Specimens were machined from a blank of four cylindrical bars, and have $0.5 \mathrm{~m}$ in length, and $11 \mathrm{~mm}$ in diameter. They are machined using a dressing tool with a carbide tip (Fig. 1), being its geometry described in Table 3. The tool penetrates the workpiece by minimizing the friction with the lubricant. For a superfinishing surface quality in turning operation, it is necessary to choose suitable cutting parameters. A. Chevallier [25] mentioned that austenitic stainless steel must be machined with a feed superior then $0.04 \mathrm{~mm} / \mathrm{rev}$, and a cutting speed environs $115 \mathrm{~m} / \mathrm{min}$. In the one hand, the field experiment uses feed values belong to the interval [0.05 $\mathrm{mm} / \mathrm{tr} ; 0.2 \mathrm{~mm} / \mathrm{tr}]$. The upper value of the range $(0.2 \mathrm{~mm} / \mathrm{tr})$ was selected to remain in the finishing operation, and to avoid the roughing rang of feed. Based on the average value of feed interval $(0.125 \mathrm{~mm} / \mathrm{tr})$, Corner Radius can be calculated according to equation 1 used in mechanical industry [26]. This value is equal to $0.2 \mathrm{~mm}\left(0.125^{*} 2=0.25 \approx 0.2 \mathrm{~mm}\right)$. In the other hand, the cutting speed adopts $115 \mathrm{~m} / \mathrm{min}$ value as the arithmetic average of the selected range, so the interval $[75 \mathrm{~m} / \mathrm{min} ; 150 \mathrm{~m} / \mathrm{min}$ ] has been chosen (equation 2). The experimental design of the cutting parameters is presented in Table 3.

$$
\begin{gathered}
r_{\varepsilon}=2 . f \\
\frac{75+150}{2}=112.5 \cong 115 \mathrm{~m} / \mathrm{mm}
\end{gathered}
$$

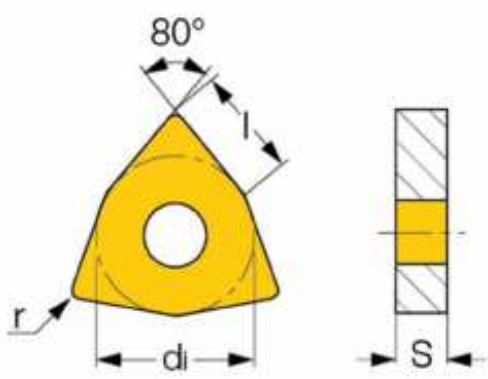

Figure 1. Carbide tip WNMG 080004-11 NS9530.

Table 3. Input cutting parameters of the experiment.

\begin{tabular}{ccc}
\hline \multicolumn{3}{c}{ Range } \\
\hline $\mathbf{F}$ & 0.05 & 0.2 \\
\hline $\mathbf{a p}$ & 0.25 & 1 \\
\hline Vc & 75 & 150 \\
\hline
\end{tabular}




\section{Localized corrosion tests}

Corrosive solution

A $6 \% \mathrm{NaCl}$, obtained by diluting of sea salt with distilled water.

\section{Electrochemical measurements}

The electrochemical experiments were performed in a Pyrex cell with three electrodes (Fig. 2): stainless steel UNS S31600 $\left(1 \mathrm{~cm}^{2}\right)$ as working electrode, platinum as an auxiliary electrode and a saturated calomel electrode, SCE, as a reference electrode. The current-potential curve is obtained by operating in potentiodynamic mode; the potential applied to the sample varies continuously with a scanning rate of $5 \mathrm{mV} / \mathrm{min}$. A relatively low rate of scanning was chosen to remain in a quasi-stationary regime. The measurements are performed with an assembly comprising a PGZ100 potentiostat-galvanostat, associated with "voltamaster4" software. Before curve plot, the working electrode is maintained at a potential of $-800 \mathrm{mV}$ for 15 minutes. The tests were carried out maintaining the temperature of the electrolyte at $25{ }^{\circ} \mathrm{C} \pm 0.1^{\circ} \mathrm{C}$.

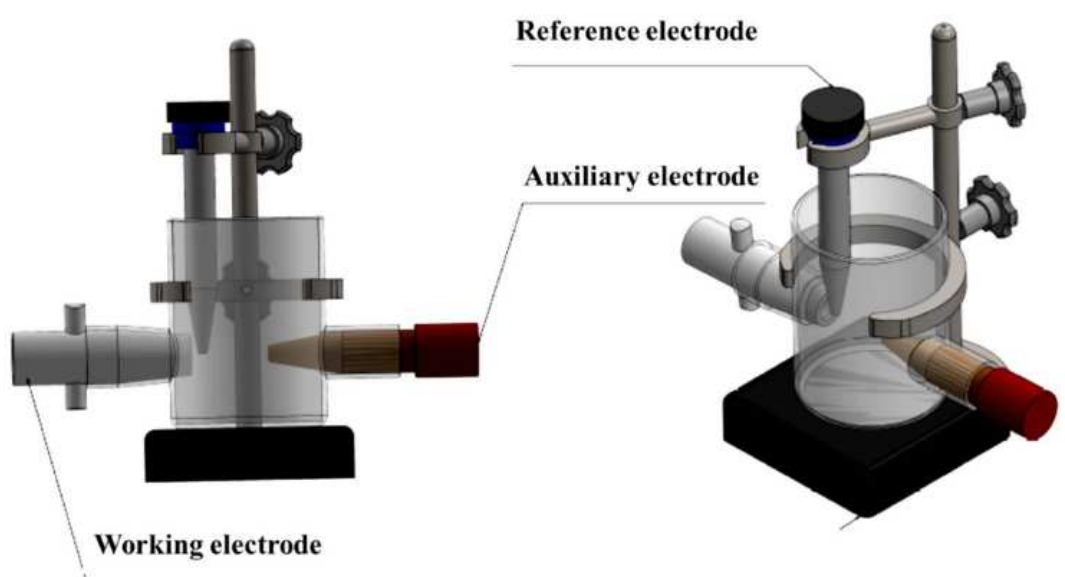

Figure 2. The Pyrex cell with three electrodes.

\section{Results and discussion \\ Surface roughness}

The average roughness $R a$ of the machined specimens in the superfinish turning is shown in Table 4.

The cutting speed $V c$ had an influence on the average roughness $R a$ in superfinish turning. Fig. 3 proves that the increase in the cutting speed conducts to decreasing the quality of surface workpiece of l'UNS S31600. The same finding was observed on the variation of the average roughness with the depth of cut, as presented in Fig. 4. This observation approves the degradation of the surface quality with the increase in the depth of cut ap.

In turning operation, increasing the depth of cut and the cutting speed generates a mechanical vibration on the cutting tool, and a thermal constraint, produced by the tool friction in machining operation [27]. Stainless steel has a low thermal conductivity that prevents dissipation of heat generated in the cutting area, consequently increasing the cutting temperature [28]. Therefore, high temperatures with high ductility of the austenite phase increase the residual stress 
in the subsurface layer of workpiece. Consequently, this stress impacts the material nobility, and increases corrosion potential.

Table 4. Variation of average roughness with cutting conditions.

\begin{tabular}{ccccc}
\hline $\mathbf{N}^{\circ}$ & $\mathbf{f}(\mathbf{m m} / \mathbf{t r})$ & $\mathbf{a p}(\mathbf{m m})$ & $\mathbf{V c}(\mathbf{m} / \mathbf{m i n})$ & $\mathbf{R a}(\boldsymbol{\mu m})$ \\
\hline $\mathbf{1}$ & 0.05 & 0.75 & 125 & 0.512 \\
\hline $\mathbf{2}$ & 0.1 & 0.25 & 100 & 0.601 \\
\hline $\mathbf{3}$ & 0.1 & 0.5 & 100 & 0.789 \\
\hline $\mathbf{4}$ & 0.1 & 0.75 & 150 & 0.741 \\
\hline $\mathbf{5}$ & 0.15 & 0.25 & 125 & 0.902 \\
\hline $\mathbf{6}$ & 0.15 & 0.5 & 150 & 0.960 \\
\hline $\mathbf{7}$ & 0.15 & 0.75 & 150 & 1.089 \\
\hline $\mathbf{8}$ & 0.2 & 0.25 & 125 & 1.215 \\
\hline $\mathbf{9}$ & 0.2 & 0.25 & 150 & 1.332 \\
\hline $\mathbf{1 0}$ & 0.2 & 0.5 & 100 & 1.476 \\
\hline $\mathbf{1 1}$ & 0.2 & 0.5 & 150 & 1.575 \\
\hline $\mathbf{1 2}$ & 0.2 & 0.75 & 75 & 0.490 \\
\hline $\mathbf{1 3}$ & 0.2 & 0.75 & 100 & 1.774 \\
\hline
\end{tabular}

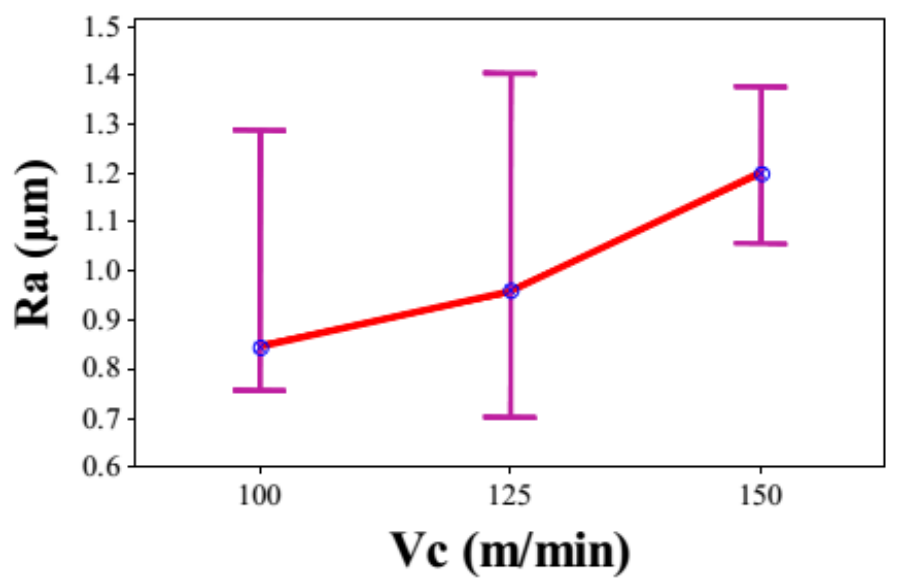

Figure 3. The variation of average roughness Ra with the cutting speed Vc.

The average roughness increases with increasing the feed per revolution (Fig. 5). The lower quality of machined surface has not limited in this increase in roughness, but it was illustrated on the large dissipation of roughness values for higher feeds. Therefore, the range of dissipation increases with the increase in feed per revolution of cutting tool. This increase of dissipation range was influenced by increasing vibration on the cutting tool in finish turning operation [29]. 


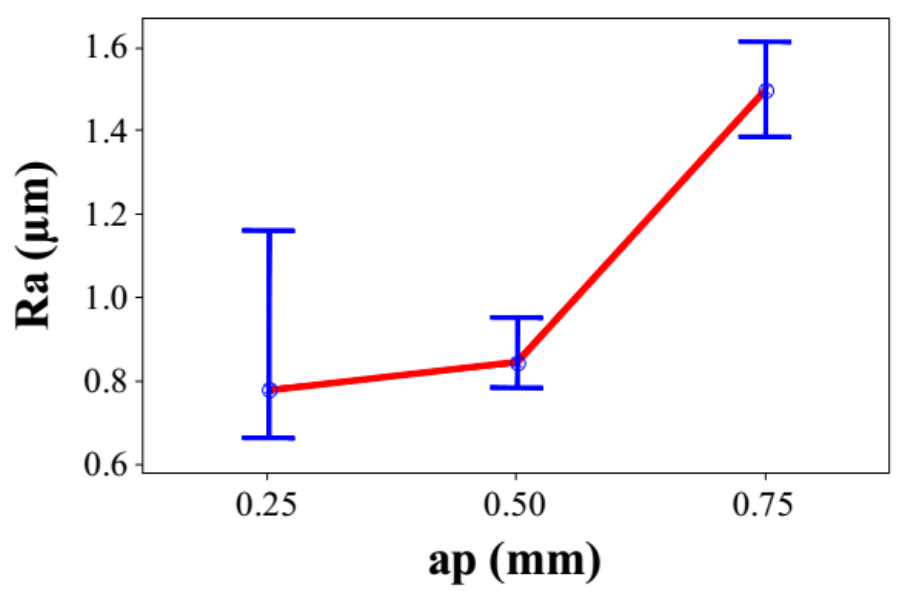

Figure 4. The variation of average roughness $R a$ with the depth of cut $a p$.

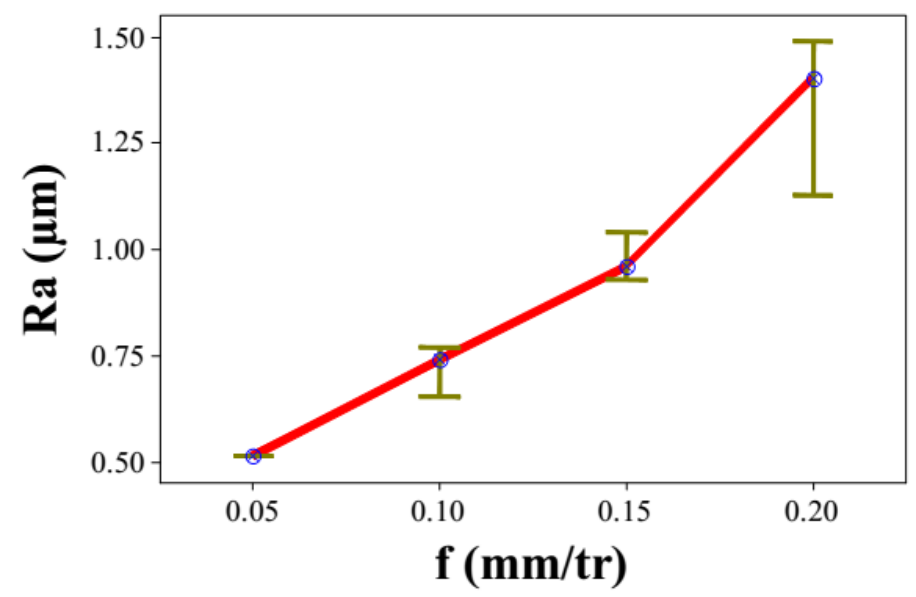

Figure 5. The variation of average roughness $\mathrm{Ra}$ with the feed per revolution $\mathrm{f}$.

\section{Corrosion resistance}

The evolution of the corrosion potential was studied with the machined surface behavior. This study consists in examining the variation of the polarization resistance $R p$, the corrosion current density $I_{c o r r}$ and the corrosion potential $E_{\text {corr }}$, with the average roughness $R a$ of UNS S31600 workpiece in superfinish turning.

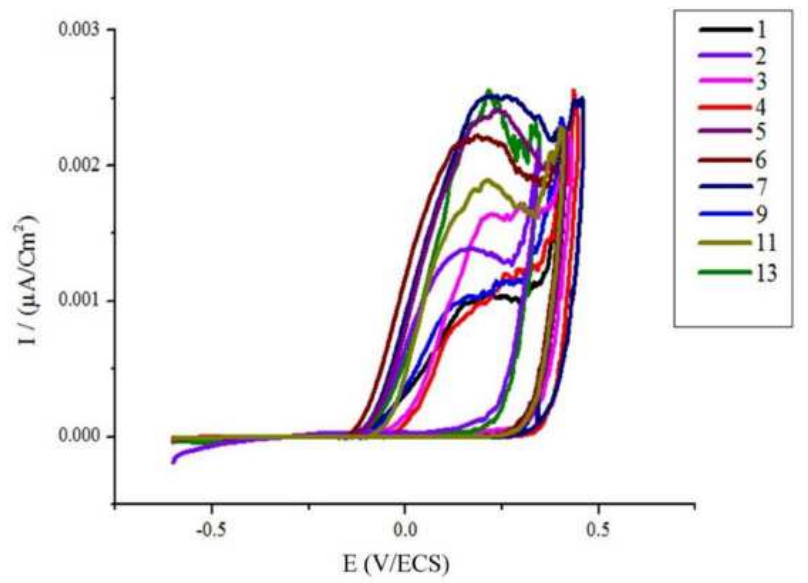

Figure 6. Potentiodynamic curves obtained from machined specimens with different superfinish parameters. 
The potentiodynamic curves obtained from machined specimens with different superfinish parameters were compared in Fig. 6. The specimens were machined in different values of the cutting speed, the feed and the depth of cut. The roughness parameters after the superfinish turning tests and the physico-chemical parameters were represented in Table 5.

Table 5. Variation of average roughness with the polarization resistance $\mathrm{Rp}$, the corrosion potential $\mathrm{E}_{\mathrm{corr}}$ and the corrosion density of current $\mathrm{I}_{\text {corr. }}$

\begin{tabular}{|c|c|c|c|c|c|c|c|}
\hline $\mathbf{N}^{\circ}$ & $\begin{array}{c}\mathbf{f} \\
(\mathrm{mm} / \mathrm{tr})\end{array}$ & $\begin{array}{c}\text { ap } \\
(\mathbf{m m})\end{array}$ & $\begin{array}{c}\text { Vc } \\
(\mathrm{m} / \mathrm{min})\end{array}$ & $\begin{array}{c}\mathbf{R a} \\
(\mu \mathrm{m})\end{array}$ & $\begin{array}{c}\text { Rp } \\
\left(\Omega \cdot \mathrm{cm}^{2}\right)\end{array}$ & $\begin{array}{c}\text { E }_{\text {corr }} \\
(\mathrm{mV} / \mathrm{ECS})\end{array}$ & $\begin{array}{c}\text { Icorr } \\
\left(\eta \mathbf{A} / \mathrm{cm}^{2}\right)\end{array}$ \\
\hline 1 & 0.05 & 0.75 & 125 & 0.512 & 30000 & -318 & 1205.5 \\
\hline 2 & 0.10 & 0.25 & 100 & 0.601 & 1290000 & -320.1 & 1260.0 \\
\hline 3 & 0.10 & 0.50 & 100 & 0.789 & 1290000 & -304.6 & 281.8 \\
\hline 4 & 0.10 & 0.75 & 150 & 0.741 & 36410 & -305.9 & 1001.4 \\
\hline 5 & 0.15 & 0.25 & 125 & 0.902 & 1800000 & -260.7 & 29.0 \\
\hline 6 & 0.15 & 0.50 & 150 & 0.960 & 1250000 & -240.4 & 21.8 \\
\hline 7 & 0.15 & 0.75 & 150 & 1.089 & 380280 & -230.8 & 418.9 \\
\hline 8 & 0.20 & 0.25 & 125 & 1.215 & 1254448 & -214.5 & 21.8 \\
\hline 9 & 0.20 & 0.25 & 150 & 1.332 & 186960 & -216.3 & 20.9 \\
\hline 10 & 0.20 & 0.50 & 100 & 1.476 & 1180000 & -222.1 & 71.0 \\
\hline 11 & 0.20 & 0.50 & 150 & 1.575 & 689440 & -232.4 & 110.8 \\
\hline 12 & 0.20 & 0.75 & 75 & 1.490 & 322810 & -290.4 & 94.1 \\
\hline 13 & 0.20 & 0.75 & 100 & 1.774 & 25400 & -296.9 & 1024.8 \\
\hline
\end{tabular}

Fig. 6 and Table 5 indicate that the average roughness impact the passivation processes of UNS S31600. The current-potential curves were influenced by the average roughness $R a$. The domain of inertia is the same for all specimens. However, the active domain has established differently according to the average roughness of UNS S31600. The corrosion potential has ennobled since -320 $\mathrm{mV} / \mathrm{ECS}$ to $-210 \mathrm{mV} / \mathrm{ECS}$.

The corrosion current density was varied with the surface quality of the workpiece. The average roughness value $1.774 \mu \mathrm{m}$ (workpiece $\mathrm{N}^{\circ} 13$ ) corresponds to the current density $1.0248 \mu \mathrm{A} / \mathrm{cm}^{2}$. This value of $\mathrm{I}_{\text {corr }}$ increases to $1.0014 \mu \mathrm{A} / \mathrm{cm}^{2}$ for an average roughness lower $(\mathrm{Ra}=0.751 \mu \mathrm{m})$, as far as the current density increases to $0.0941 \mu \mathrm{A} / \mathrm{cm}^{2}$ for the roughness $0.490 \mu \mathrm{m}$. This observation approves the impact of the average roughness in the corrosion current density, and consequently in the corrosion rate of UNS S31600 stainless steel. Whereas, the corrosion rate increases with the increase in the number of pits, and corrosion potential decreases with decreasing the surface quality of a workpiece [16].

The potentiodynamic tests reveal that the corrosion potential of workpieces machined in superfinish turning, increases with increasing roughness values in a 
range lower than $1.3 \mu \mathrm{m}$. The higher quality of machined surface generates a lower potential. However, this increase has stopped when the average roughness reaches $1.332 \mu \mathrm{m} \quad\left(\mathrm{E}_{\mathrm{corr}}=-216.3 \mathrm{mV} / \mathrm{ECS}\right)$. Then, the corrosion potential decreases with increasing the average roughness values (Fig. 7). Therefore, in superfinish roughness range (values inferior to $1 \mu \mathrm{m}$ ), the more the surface quality is higher, the more the corrosion potential is lower. This variation $(R a$ according to $E_{c o r r}$ ) follows a polynomial interpolation of degree 3 with a $95 \%$ correlation.

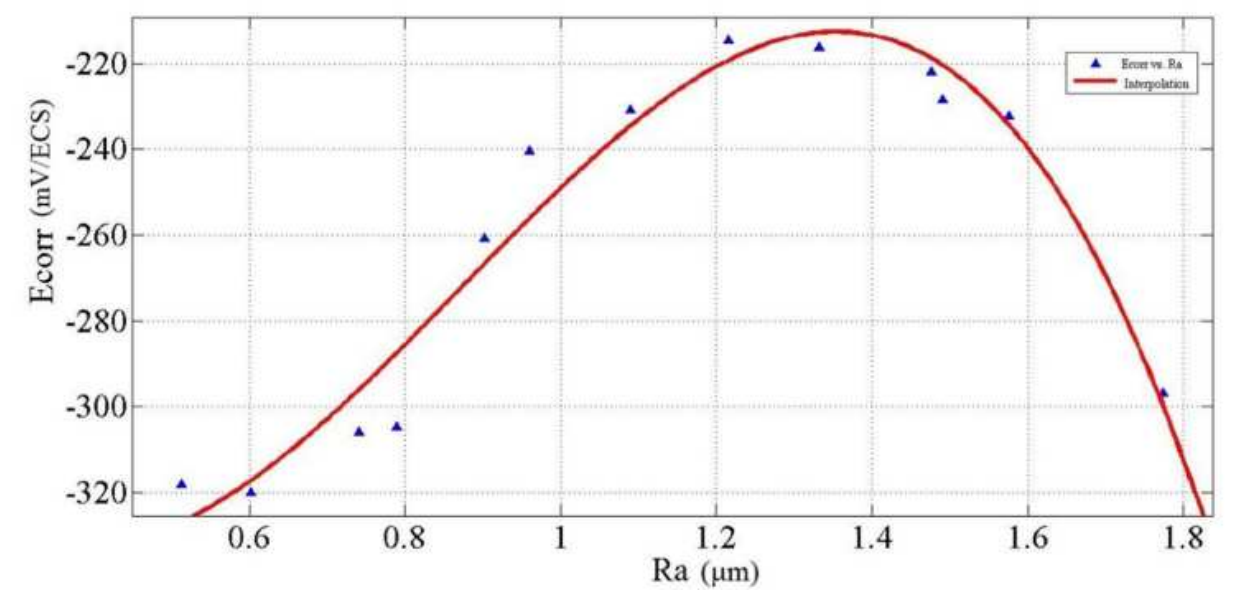

Figure 7. Evolution of the corrosion potential Ecorr with the average roughness Ra.

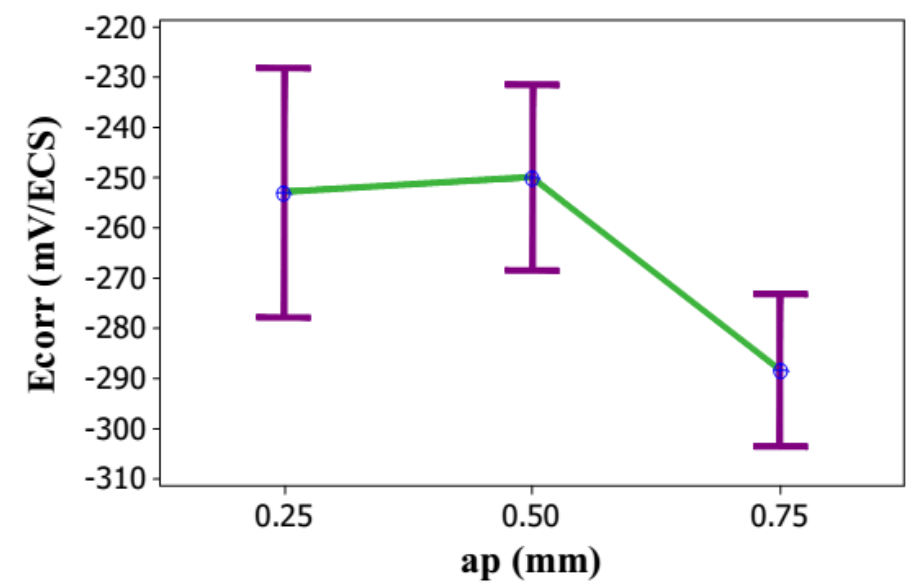

Figure 8. Variation of the corrosion potential $E_{\text {corr }}$ with the depth of cut ap.

The average roughness range $[0.512 \mu \mathrm{m} ; 1.332 \mu \mathrm{m}]$, where the corrosion potential increases, is characterized by its low values of depth of cut $(0.25 \mathrm{~mm}$ and $0.5 \mathrm{~mm}$ ). Therefore, the other range (superior than $1.332 \mu \mathrm{m}$ ) is characterized by a higher value of ap $(0.75 \mathrm{~mm})$. This remark is marked in Fig. 8; the corrosion potential has increased clearly for $0.75 \mathrm{~mm}$ value of depth of cut. However, the potential is more stable for the others values $(0.25 \mathrm{~mm}$ and 0.5 $\mathrm{mm})$. The cutting depth ap does not affect the residual stress for lower values, so the corrosion behavior of stainless steel was more stable in this range [30]. Nevertheless, for greater values, the vibration increases with the increase in the 
cutting depth [31]. Therefore, the residual stress was appeared and accelerates the corrosion reaction of the workpiece.

The cutting speed affects the corrosion potential. The more the cutting speed increases, the more the potential increases, especially, more the corrosion resistance of stainless steel is higher. The cutting speed affects the plastic deformation rate of the workpiece. When the cutting speed increases, the corrosion rate decreases (Fig. 9). This increase in the speed develops the deformation rate. Consequently, the $\beta$-phase of material was appeared, which acts as non-protective component. This thin layer characterizes the rough surface. On the other hand, for the smooth surfaces, $\alpha$ and $\gamma$ phases occupy greater area of the workpiece, which acts as protective component [19].

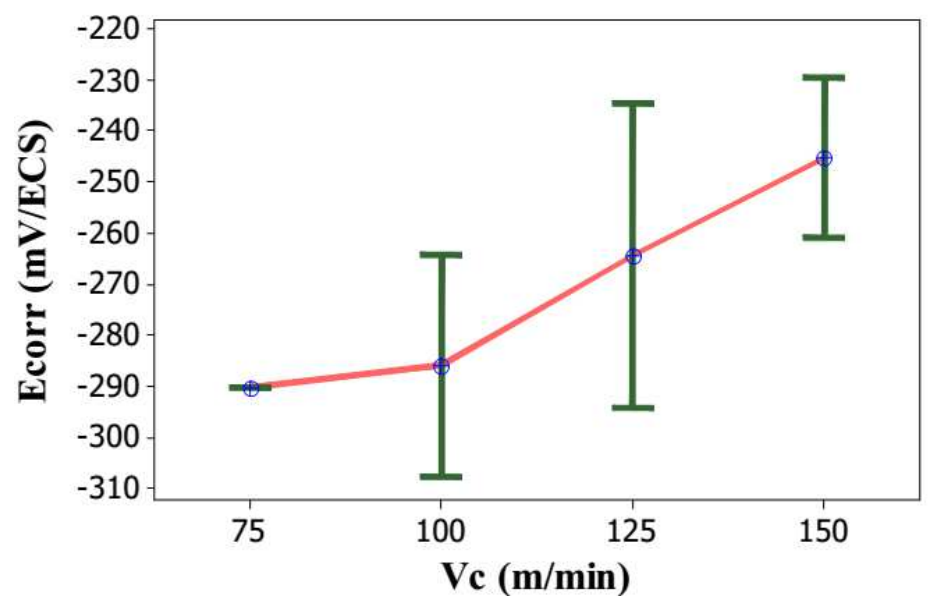

Figure 9. Variation of the corrosion potential $\mathrm{E}_{\text {corr }}$ with the cutting speed Vc.

Comparing this investigation with others in literature, V. Zatkalìkovã et al. [16] have affirmed that the pitting corrosion parameters have been affected by the average roughness of workpiece.

They have affirmed that the nobility of the stainless steel decreases with the increase in the average roughness values (Table 6).

Table 6. Corrosion resistance of stainless steel [18].

\begin{tabular}{lccc}
\hline Surface treatment & Ra $(\boldsymbol{\mu m})$ & $\mathbf{R p}(\mathbf{\Omega . c m})$ & Ecorr $(\mathbf{m V})$ \\
\hline Turning & 3.00 & 2650 & -123 \\
\hline Turning and pickling & 2.44 & & -82 \\
\hline Shot peening & 3.24 & 147 & -150 \\
\hline Shot peening and pickling & 3.48 & & -72 \\
\hline Abrasive blasting in $\mathbf{4 5}^{\circ}$ & 2.64 & 130 & -180 \\
\hline Abrasive blasting in $\mathbf{4 5}^{\circ}$ and pickling & 2.24 & & -3 \\
\hline Abrasive blasting in $\mathbf{9 0}^{\circ}$ & 4.32 & 120 & -185 \\
\hline Abrasive blasting in $\mathbf{9 0}^{\circ}$ and pickling & 2.30 & & -13 \\
\hline
\end{tabular}

Also, W. Bouzid Sai et al. [11] arrived to the same results. They have revealed that the decrease in the average roughness provokes the increase in corrosion resistance, and, consequently, the increase in pitting potential, caused by the decrease of the residual stress. This decrease can be due to the diminution of the hardened layer of smooth surface (Table 7). 
Table 7. Corrosion resistance of stainless steel in different manufacturing procedures [13].

\begin{tabular}{lcc}
\hline Procedure & Ra $(\boldsymbol{\mu m})$ & $\mathbf{E}_{\text {corr }}(\mathbf{m V} / \mathbf{E C S})$ \\
\hline T : Roughing & 0.687 & -200 \\
\hline $\mathbf{R}_{\mathrm{T}}:$ Rectification & 0.598 & -75 \\
\hline $\mathbf{G}_{\mathrm{T}}:$ Burnishing & 0.160 & -100 \\
\hline $\begin{array}{l}\text { GRT }_{\mathrm{R}}: \text { Rectification }+ \\
\text { Burnishing }\end{array}$ & 1.175 & -300 \\
\hline
\end{tabular}

The polarization resistance $R p$ increases with the amelioration of the surface quality (smooth surface). The more the average roughness is low, the more the polarization resistance is high. This variation has a polynomial interpolation with 91\% correlation (Fig. 10).

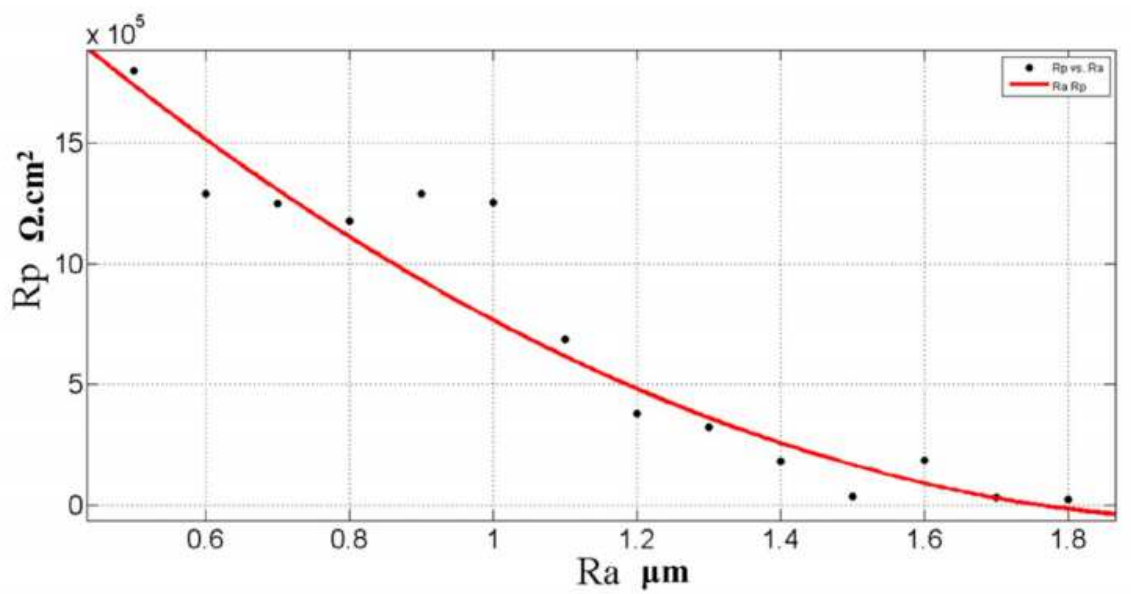

Figure 10. Evolution of the polarization resistance Rp with the average roughness Ra.

The impact of cutting parameters, especially the depth of cut and the cutting speed, was illustrated in Fig. 11 and Fig. 12.

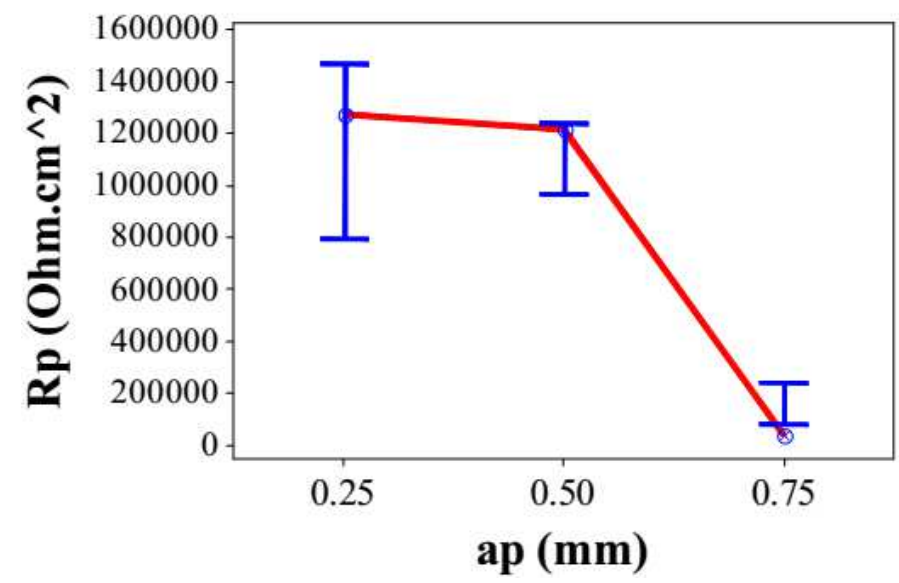

Figure 11. Variation of the polarization resistance Rp with the depth of cut ap.

The polarization resistance decreases clearly after $\mathrm{Vc}=125 \mathrm{~m} / \mathrm{min}$ and $\mathrm{ap}=0.5$ $\mathrm{mm}$, so the corrosion resistance of stainless steel degrades. Therefore, the 
amelioration of UNS S31600 corrosion resistance was due to the higher surface quality and the decrease in residual stress, caused especially by the chosen cutting conditions.

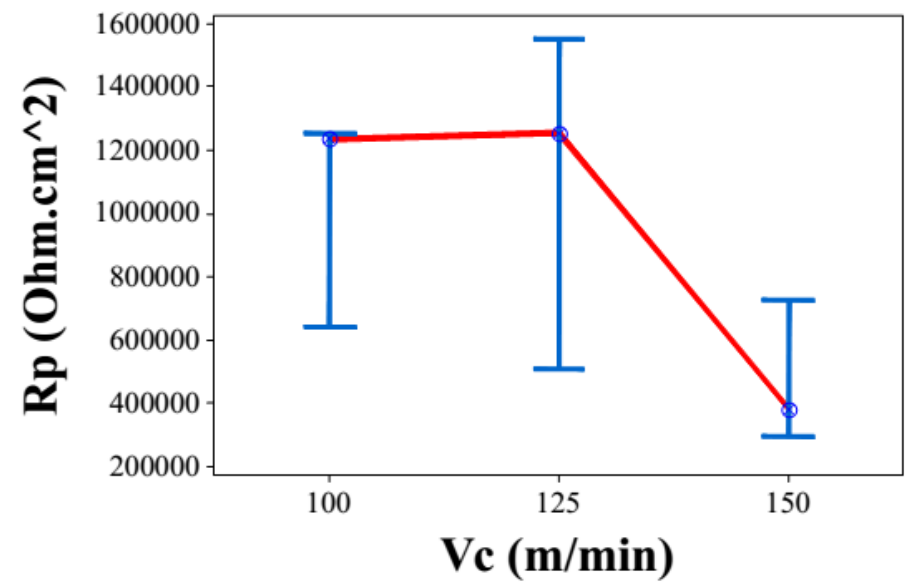

Figure 12. Variation of the polarization resistance Rp with the cutting speed Vc.

However, the feed $f$ has not any significant correlation with the polarization resistance (Fig. 13).

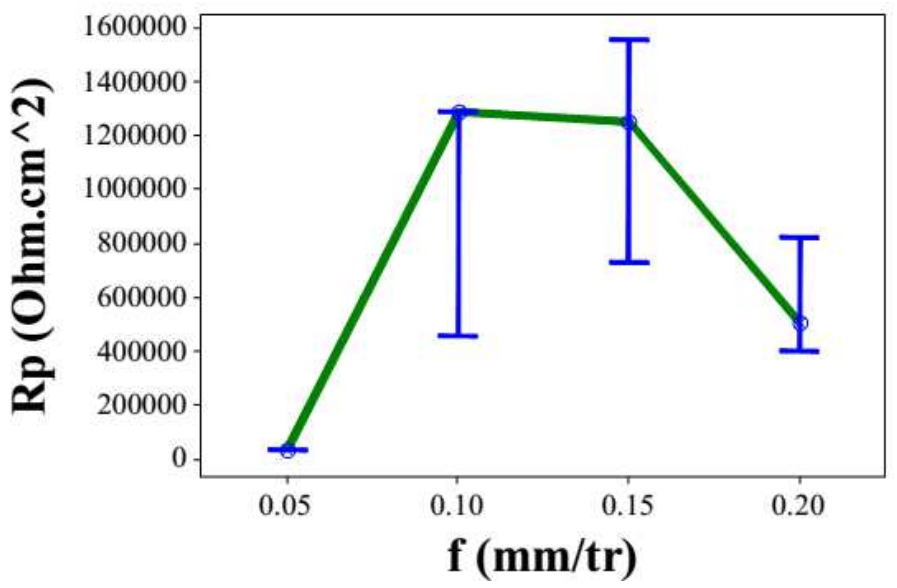

Figure 13. Variation of the polarization resistance $\mathrm{Rp}$ with the feed $\mathrm{f}$.

\section{Conclusions}

The superfinish turning of UNS S31600 stainless steel affects the localized corrosion resistance. The results are grouped into the following:

- In superfinish turning ( $\mathrm{Ra}<1 \mu \mathrm{m}$ ), the corrosion resistance of UNS S31600 stainless steel decreases, reducing the metal dissolution. However, in finish turning $(1 \mu \mathrm{m}<\mathrm{Ra}<6.3 \mu \mathrm{m})$, the decrease in roughness value provokes a diminution in corrosion potential.

- The depth of cut affects the corrosion potential. The increase in this factor generates the residual stress in the thin subsurface layer, which causes a decrease in potential, reducing the metal dissolution and the passivation layer.

- The cutting speed affects the corrosion potential. Its increase $(V c)$ degrades the corrosion resistance and increases the corrosion potential. 
- The polarization resistance increases with the increase in surface quality with 91\% correlation. Consequently, the amelioration of the corrosion resistance with the increase in surface quality of the UNS S31600 workpiece in superfinish turning.

\section{References}

1. Hashimotoa F, Chaudharia RG, Melkoteb SN. Characteristics and Performance of Surfaces Created by Various Finishing Methods. Procedia CIRP. 2016;45:1.

2. Mittal S, Liu C. A method of modeling residual stresses in superfinish hard turning. Wear. 1998;218: 21.

3. Endrino J, Fox-Rabinovich G, Gey C. Hard AlTiN, AlCrN PVD coatings for machining of austenitic stainless steel. Surf Coat Tech. 2006;200:6840.

4. Asiltürk I, Çunkas M. Modeling and prediction of surface roughness in turning operations using artificial neural network and multiple regression method. Expert Syst Appl. 2011;38:5826.

5. Grzesik W, Zak K. Modification of surface finish produced by hard turning using superfinishing and burnishing operations. J Mater ProcessTech. 2012;212:315.

6. Valiorgue F, Rech J, Hamdi H, et al. 3D modeling of residual stresses induced infinish turning of an AISI304L stainless steel. Int J Machin Tools Manuf. 2012;53:77.

7. Stenberg N, Proudian J. Numerical modelling of turning to find residual stresses. Procedia CIRP. 2013;8:258.

8. Abboud E, Shi B, Attia H, et al. Finite element-based modeling of machining-induced residual stresses in Ti-6Al-4V under finish turning conditions. Procedia CIRP. 2013;8:63.

9. Caruso S, Di Renzo S, Umbrello D, et al. Finite Element Modeling of Microstructural Changes in Hard Turning. Adv Mater Res. 2011;223:960.

10. $\mathrm{Pu} \mathrm{Z}$, Umbrello $\mathrm{D}$, Dillon $\mathrm{Jr} \mathrm{O}$, et al. Finite element modeling of microstructural changes in dry and cryogenic machining of AZ31B magnesium alloy. J Manuf Proc. 2014;16:335.

11. Liu CR, Mittal S. Single-step superfinish hard machining: Feasibility and feasible cutting conditions. Rob Comp lnteg Manuf. vol. 12, pp. 15-27, 1995.

12. Navas GV, Gonzalo O, Bengoetxa I. Effect of cutting parameters in the surface residual stresses generated by turning in AISI 4340 steel. Int J Machin Tools Manuf. 2012;61:48.

13. Sai WB, Triki E. Influence of machined surface characteristics on a Duplex stainless steel corrosion resistance. Trans Canad Soc Mech Eng. 2006;30:183.

14. Gurvich L, Shubadeeva L. Effect of machining on Corrosion Resistance in Stainless steels. All-Union Aviat Mater Sci-Res Inst. 1971;7:23.

15. Szklarska-Smialowska Z. Pitting and Crevice Corrosion. Houston, Texas: NACE International; 2005. 
16. Zuo Y, Wang H, Zhao J. et al. The effects of some anions on metastable pitting of 316L stainless steel. Corros Sci. 2002;44:13.

17. Sasaki K, Burstein G. "The generation of surface roughness during slurry erosion-corrosion and its effect on the pitting potential. Corros Sci. 1996;38:2111.

18. Zatkalíková V, Liptáková T. Pitting corrosion of stainless steel at the various surface treatment," Mater Eng. 2011;18:115.

19. Prakash M, Shekhar S, Moon A. et al. Effect of machining configuration on the corrosion of mild steel. J Mater Proc Tech. 2015;219:70.

20. Lee SM, Lee WG, Kim YH, et al. Surface roughness and the corrosion resistance of 21Cr ferritic stainless steel. Corros Sci. 2012;63:404.

21. Gravier J, Vignal V, Bissey-Breton S, et al. The use of linear regression methods and Pearson's correlation matrix to identify mechanical-physicalchemical parameters controlling the micro-electrochemical behaviour of machined copper. Corros Sci. 2008;50:2885.

22. Bissey-Breton S, Gravier J, Vignal V. Impact of superfinish turning on surface integrity of pure copper. Proc Eng. 2011;19:28.

23. Yin S, Li D. Effects of prior cold work on corrosion and corrosive wear of copper in HNO3 and NaCl solutions. Mater Sci Eng A. 2005;394:266.

24. Robin A, Martine GAS, Suzuki PA. Effect of cold-working process on corrosion behavior of copper. Mat Design. 2012;34:319.

25. Chevalier A, Bohan J. Guide du technicien en productique. Paris: Hachette Livre; 1996.

26. Grzesik W. Adv Machining Proc Metallic Mater. 2006.

27. Maurel A, Fontaine M, Thibaud S, et al. Modélisation thermo-élastoviscoplastique du comportement de l'acier inoxydable 304L - Applications à l'usinage grande vitesse. Grenoble: 18ème Congrès Français de Mécanique; 2007.

28. Fernández-Abia AI, García JB, de Lacalle LNL. High-performance machining of austenitic stainless steels. León: Woodhead Publ Ltd; 2013.

29. Marty A. Simulation numérique de l'usinage par l'outil coupant à l'echelle macroscopique: contribution à la définition géométrique de la surface usinée. Paris: Ecole Nationame supérieure d'Arts et Métiers; 2003.

30. Dahlman P, Gunnberg F, Jacobson M. The influence of rake angle, cutting feed and cutting depth on residual stresses in hard turning. J Mater Proc Tech. 2004;147:181.

31. Aleksandrovich RV, Siamak G. The Effect of Tool Construction and Cutting Parameters on Surface Roughness and Vibration in Turning of AISI 1045 Steel Using Taguchi Method. Modern Mech Eng. 2014;4:8. 